\title{
Bacterial infection complicating varicella infection: A 10-year review of hospitalized children
}

\author{
Golda Milo-Manson, MD, Carol Portwine, MD, Elaine Wang, MD, CM
}

\begin{abstract}
G MLO-MANSON, C PoRTwine, E WANG. Bacterial infection complicating varicella infection: A 10-year review of hospitalized children. Can $J$ Infect Dis 1993;4(2):108-110. An increased incidence of Streptococci pyogenes (group A streptococcus [GAS]) infections and rheumatic fever has been reported over the past decade. The present study was conducted to determine whether a similar increase in such infections was observed after varicella, an infection previously shown to be associated with a high incidence of streptococcal infections. The charts of all children admitted with chickenpox to the Hospital for Sick Children in Toronto, Ontario from January 1, 1980 to December 31, 1989 were reviewed. Immunocompromised children and those hospitalized for another reason who had an incidental diagnosis of chickenpox were excluded. Twenty-five cases with bacterial infection complicating chickenpox were compared with 103 patients without secondary infection. No statistically significant differences were observed for age, gender, duration of illness prior to hospitalization or duration of hospitalization in the two groups. GAS was the most frequent isolate in the cases, followed by Staphylococcus aureus, Escherichia coli and Haemophilus influenzae. The types of infection were significantly different for GAS compared with other organisms, with a predominance of skin infections in the former group $\left(\chi^{2}\right.$ analysis, $\left.\mathrm{P}<0.05\right)$. No increase in the incidence of GAS infections was observed over time. This study confirms the importance of GAS infections in patients with varicella, but no increase was observed in hospitalized children during the 10-year study period.
\end{abstract}

Key Words: Streptococcal infection, Superinfection, Varicella

\section{Infection bactérienne compliquant une infection de varicelle : une revue d'enfants hospitalisés sur une période de 10 ans}

RÉSUMÉ: Au cours des dix derrières années, on a observé une incidence accrue des infections à Streptococci pyogenes (Streptococcus groupe A [GAS]) et des cas de rhumatisme articulaire aigu. La présente étude a été effectuée pour déterminer si une augmentation similaire de ces infections a été notée après des cas de varicelle, une infection ayant précédemment montré une association fréquente à des infections streptococciques. Les dossiers de tous les enfante admis avec une varicelle à l'Hospital for Sick Children de Toronto (Ontario) du $1^{\mathrm{er}}$ janvier 1980 au 31 décembre 1989 ont été passés en revue; ont été exclus: les enfante immunodéficients et ceux qui avaient été hospitalisés pour d'autres raisons mais qui avaient fait l'objet d'un diagnostic incident de varicelle. Aucune différence statistiquement significative n'a été observée entre les deux groupes, en ce qui concerne l'âge, la sexe, la durée de la maladie avant l'hospitalisation ou la durée de l'hospitalisation. Le streptocoque GAS était l'isolat la plus fréquemment observé, suivi de Staphylococcus aureus, Escherichia coli et Haemophilus influanzae. Les types d'infection étaient significativement différents pour le streptocoque GAS en comparaison des autres micro-organismes, avec une prédominance d'infections cutanées dans le premier groupe (analyse $\chi^{2}, \mathrm{P}<0,05$ ). Aucune augmentation de l'incidence des infections à GAS n'a été observée avec le temps. Cette étude confirme l'importance des infections à GAS chez les patients atteints de varicelle, mais aucune augmentation n'a été observée chez les enfants hospitalisés pendant la période de 10 ans qu'a duré l'étude. 
NFECTIONS WITH STREPTOCOCCUS PYOGENES (GROUP A STREPtococcus [GAS]) have been reported to occur frequently after chickenpox (1-3), presumably because of breaks in the skin or impaired host response $(4,5)$. A number of rheumatic fever outbreaks have been reported (6-13), but increased incidence of rheumatic fever has not been observed in population-based studies $(14,15)$. At the same time, a toxic shock-like syndrome with high morbidity and mortality has been associated with GAS in reports from many different parts of the world (16-23).

Because previous studies describing GAS after varicella infections have consisted of case reports or descriptive series (1-5), a study examining all hospitalized varicella patients was performed to provide comparative data on the morbidity due to such infections. In order to describe the frequency and characterize the nature of complicating bacterial infections, all organisms, such as GAS, were included. The authors also wished to determine the incidence of GAS infections with varicella over a decade.

\section{SUBJECTS AND METHODS}

All charts of children with a final diagnosis of varicella hospitalized between January 1, 1980 and December 31, 1989 at the Hospital for Sick Children in Toronto, Ontario were reviewed. This is a 550-bed tertiary care pediatric hospital which serves the municipality of Toronto as well as south central Ontario, but has a referral base that includes the province of Ontario. Patients who were immunocompromised (defined as patients who were receiving or had received cancer chemotherapy, children with congenital or acquired immunodeficiency and children who had received a bone marrow, liver or kidney transplant) were excluded. Because of their underlying disease, these patients would be expected to have problems which are quite different from those of the immunocompetent host. In addition, patients who were hospitalized for another reason, such as trauma or elective surgery, who then developed chickenpox coincidentally while in hospital were excluded because they would not represent children admitted with the disease.

Patients were divided into those who developed a secondary infection and those who did not. A second infection required recovery of a bacterial or fungal agent from blood or an infected site. Patients from whom coagulase negative staphylococci or alpha-hemolytic streptococci were recovered only once were excluded.

A $\chi^{2}$ test was used for comparisons of proportions between two groups. For continuous variables, a MannWhitney U nonparametric test was used for comparison.

\section{RESULTS}

One hundred and twenty-eight charts met eligibility criteria for further review. Of these, 25 patients were designated as cases and 103 were controls. The major-

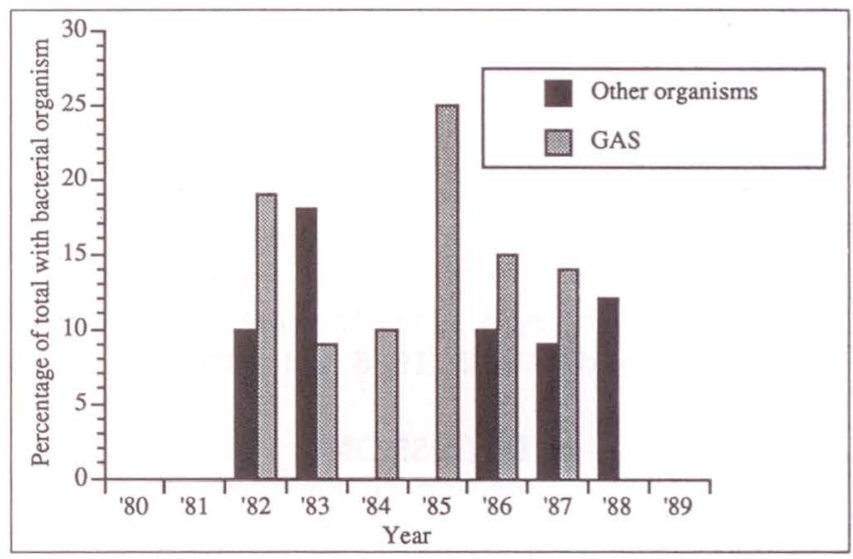

Figure 1) Yearly proportion of cases and controls with group $A$ streptococcal (GAS) and other infections

ity of cases had skin infections; 11 patients had cellulitis and four had impetigo, counting for $60 \%$ of infections. Other types of infection were septic arthritis (three patients), pharyngitis (two), lymphadenitis (one), osteomyelitis (one) and urinary tract infection (two). No patient had severe cellulitis or toxic shock-like syndrome. Control subjects included patients who had previously been healthy and those with underlying illness. The most common diagnoses were encephalitis (16 patients), febrile convulsions (five), preceding seizure disorders (eight), idiopathic thrombocytopenic purpura (six), preceding diabetes mellitus (five), neonatal chickenpox (five) and Reye's syndrome (two). The median age (3.4 versus 4.9 years, respectively), duration of prior illness (four versus three days) and hospitalization (four days in both groups) was similar for cases and controls.

Of the 25 infections, a single isolate was recovered in all except three patients. Staphylococcus aureus was isolated in combination with another organism in all mixed infections. The other organism was GAS, coagulase negative staphylococci and an enteric streptococcus isolated from three different patients. Of the 22 infections in which an organism was isolated in pure culture, 14 patients had GAS, five had $S$ aureus, two had Escherichia coli and one had Haemophilus influenzae. There was a significant difference in the type of infections produced by GAS compared with other organisms $\left(\chi^{2}\right.$ analysis $\left.\mathrm{P}<0.04\right)$. The distribution of illnesses with GAS compared with other bacterial isolation were cellulitis (nine versus two, respectively), impetigo (one versus three), pharyngitis (two versus none), septic arthritis (three versus none), osteomyelitis (none versus one), bacteremia (none versus one), urinary tract infection (none versus two) and lymphadenitis (none versus one). There was no significant difference between patients infected with GAS compared with those infected with other organisms with respect to age, duration of illness prior to hospitalization and hospital stay (Mann-Whitney U test, $\mathrm{P}>0.1$ ). 
The distribution of GAS infections by year of admission was compared with other organisms as a proportion of the total number of patients (cases and controls) (Figure 1). No infections were observed during 1980, 1981 or 1989 . No statistically significant difference was found between the two groups $\left(\chi^{2}\right.$ analysis $\left.P>0.1\right)$. An increase in incidence of GAS cases over the 10-year study was not observed. One case each of GAS septic arthritis occurred in 1985, 1986 and 1987.

\section{DISCUSSION}

The prevalence of secondary infections in immunocompetent children hospitalized with chickenpox was found to be $20 \%$. GAS was the most frequently isolated agent causing secondary infections. Not surprisingly, the most common type of infection affected the skin.

\section{REFERENCES}

1. Griebel M, Nahlen B, Jacobs R, Dannenmaier W, Morrissy R. Group A streptococcal postvaricella osteomyelitis. J Pediatr Orthoped 1985;5:101-3.

2. Raphael S, Longenecker S, Wolfson B, Fisher M. Postvaricella streptococcal pyomositis. Pediatr Infect Dis $\mathrm{J}$ 1989:8:187-9.

3. Fishbacher C, Green S. Varicella and life-threatening streptococcal infection. Scand J Infect Dis 1987;19:519-20.

4. Christie C, Havens P, Shapiro E. Bacteremia with group A streptococci in childhood. Am J Dis Child 1988; 142:559-61.

5. Kain Z, Frogel M, Krilov L. Osteomyelitis associated with varicella infection. Pediatr Infect Dis J 1989;8:473-4.

6. Bisno AL. The resurgence of acute rheumatic fever in the United States. Ann Rev Med 1990;41:319-29.

7. Chun L, Reddy V, Yamamoto L. Rheumatic fever in children and adolescents in Hawaii. Pediatrics 1987;79:549-52.

8. Wald ER, Dashefsky B, Feidt C, Chiponis D, Byers C. Acute rheumatic fever in Western Pennsylvania and the tristate area. Pediatrics 1987;80:371-4.

9. Congeni B, Rizzo C, Congeni J, Sreenivasan,V. Outbreak of acute rheumatic fever in Northeast Ohio. J Pediatr 1987;111:176-9.

10. Kaplan E, Hill H. Return of rheumatic fever. Consequences, implications and needs. J Pediatr 1987;111:244-6.

11. Veasy L, Wiedmeiier S, Orsmond G, et al. Resurgence of acute rheumatic fever in the intermountain area of the United States. N Engl J Med 1987;316:421-5.

12. Zangwill K, Wald E, Londino A. Acute rheumatic fever in Western Pennsylvania: A persistent problem into the 1990s. J Pediatr 1991;118:561-3.

13. Papadimos T, Escamilla J, Garst P, et al. Acute
No differences were observed between those with secondary superinfection compared with controls with respect to age or duration of illness prior to and after hospitalization. A population-based study would provide more accurate information about secondary infections with chickenpox because only a proportion of children with chickenpox are admitted to hospital. A hospital chart review, however, would be expected to identify more severe complications.

\section{CONCLUSIONS}

In conclusion, GAS was found to be an important agent of infection in the immunocompetent hospitalized patient with varicella. However, no increase in incidence of this organism was observed in the 10-year review of infections in this population.

rheumatic fever at a navy training center - San Diego, California. MMWR 1988;37:101-3.

14. Massell B, Chute C, Walker A, Kurland G. Penicillin and the marked decrease in morbidity and mortality from rheumatic fever in the United States. N Engl J Med 1988;318:280-6.

15. Griffiths S, Gersony W. Acute rheumatic fever in New York City (1969-1988): A comparative study of two decades. J Pediatr 1990;116:882-7.

16. Cone LA, Woodard DR, Schlievert PM, Tomory GS. Clinical and bacteriologic observations of a toxic shock-like syndrome due to Streptococcus pyogenes. N Engl J Med 1987;317:146-9.

17. Martin PR, Hoiby EA. Streptococcal serogroup A epidemic in Norway 1987-1988. Scand J Infect Dis 1990;22:421-9.

18. Givner L, Abramson J, Wasilauskas B. Apparent increase in the incidence of invasive group A beta-hemolytic streptococcal disease in children. J Pediatr 1991;118:341-6.

19. Thomas JC, Carr SJ, Fujioka K, Waterman SH. Community-acquired goup A streptococcal deaths in Los Angeles county. J Infect Dis 1989;160:1086-7.

20. Farley JD, Woo V, Shaw C, Smith JA. Invasive streptococcal disease in British Columbia. Can Dis Weekly Rep 1990;16:257-9.

21. Demers B, Simor AE, Vellend H, Low DE. Severe group A streptococcal disease - Toronto, Ontario. Can Dis Weekly Rep 1990;16:259-60.

22. Bartter T, Dascal A, Carroll K, Curley FJ. Toxic strep syndrome. A manifestation of group A streptococcal infection. Arch Intern Med 1988;148:1421-4.

23. Stevens DL, Tanner MH, Winship J, et al. Severe goup A streptococcal infections associated with a toxic shock-like syndrome and scarlet fever toxin A. N Engl J Med 1989;321:1-7. 


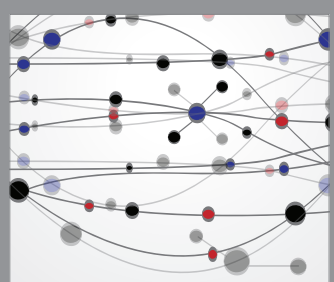

The Scientific World Journal
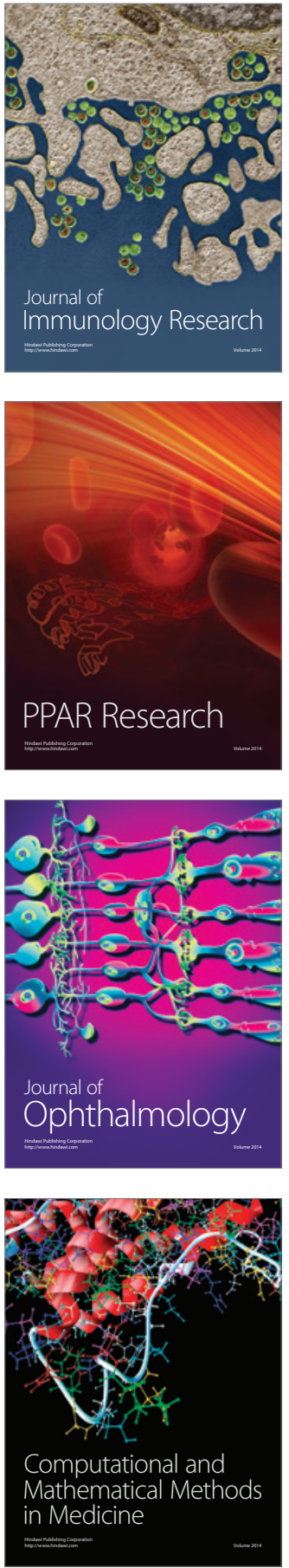

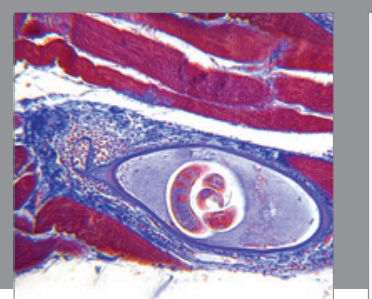

Gastroenterology Research and Practice

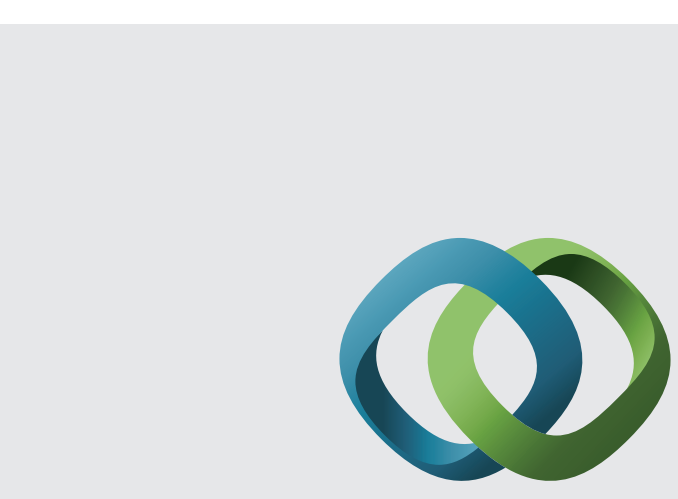

\section{Hindawi}

Submit your manuscripts at

http://www.hindawi.com
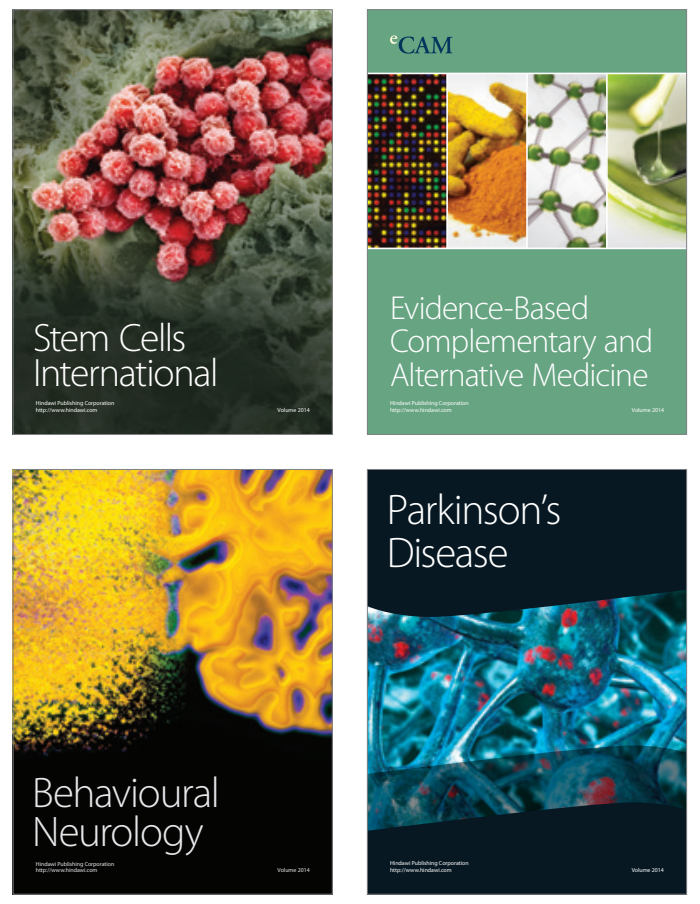
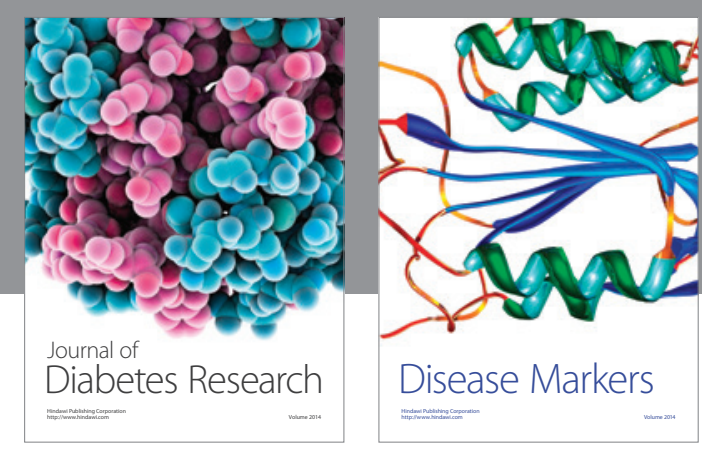

Disease Markers
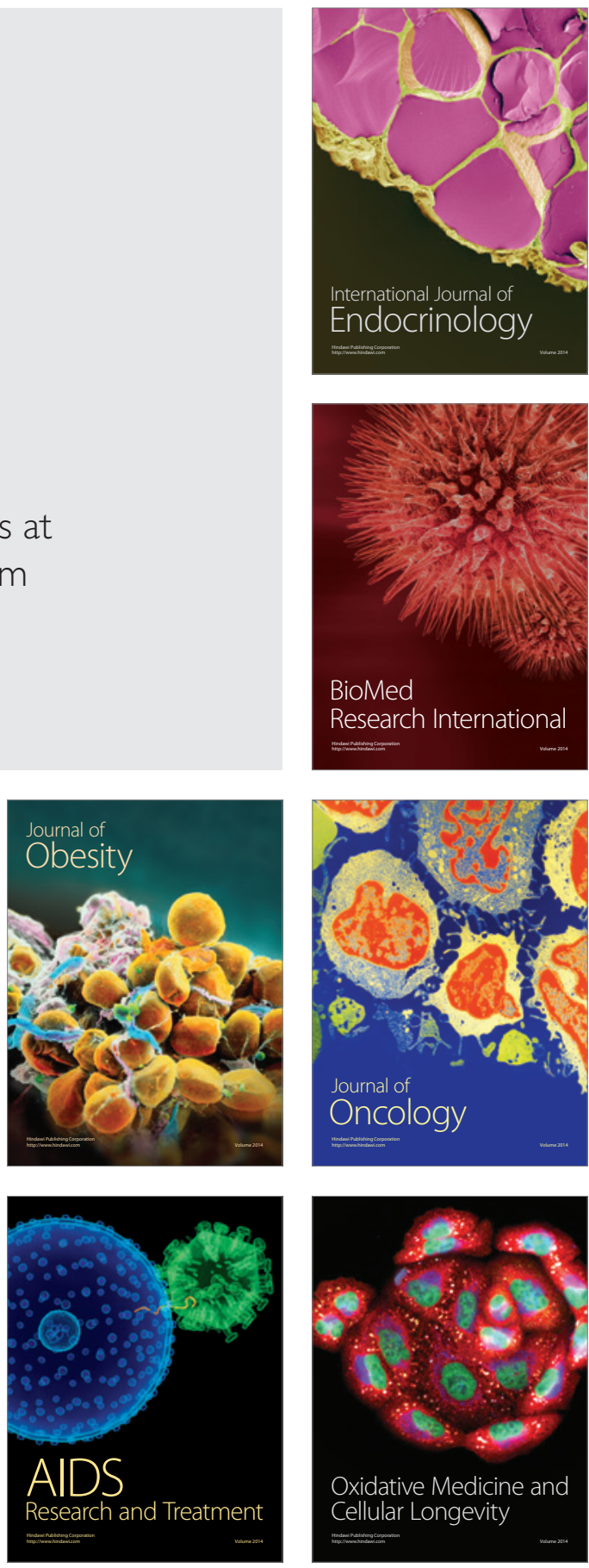